\title{
Capital Adequacy Ratio, Loan To Deposit Ratio, Non Performing Loan, Operational Cost Ratio, Net Interest Margin dan Return On Assets Perusahaan Perbankan
}

\author{
Darmansyah $^{1}$ \\ ${ }^{1}$ Universitas Pancasila, Jl. Srengseng Sawah, Jagakarsa, Jakarta Selatan 12640
}

I N F O A R T I K E L

JEL Classification:

G14

M21

Keywords:

capital adequacy ratio,

loan to deposit ratio,

non performing loan,

operational cost ratio,

net interest margin,

return on assets.

\section{A B S T R A C T}

According to Surat Edaran No. 3/30 / DPNP dated December 14, 2001, the ratio of return on assets can be measured by the ratio of profit before tax to total assets. The greater the return on assets would indicate the higher profitability. This means that the bank's financial performance is getting better. This study aims to examine the effect of capital adequacy ratio, loan to deposit ratio, non-performing loan, operational cost ratio and net interest margin of the return on assets. The results showed no effect of non-performing loans, operational cost ratio and net interest margin on profitability. Capital adequacy ratio, loan to deposit ratio proved no significant effect on profitability. This study contributes about factors that affect the profitability of the banking industry.

\section{A B S T R A K}

Menurut Surat Edaran BI No. 3/30/DPNP tanggal 14 Desember 2001, rasio return on asset dapat diukur dengan perbandingan antara laba sebelum pajak terhadap total aset. Semakin besar return on asset akan menunjukkan profitabilitas yang tinggi. Hal ini berarti kinerja keuangan bank semakin baik. Penelitian ini bertujuan menguji pengaruh capital adequacy ratio, loan to deposit ratio, non performing loan, operational cost ratio dan net interest margin terhadap return on assets. Hasil penelitian menunjukkan ada pengaruh non performing loan, operational cost ratio dan net interest margin terhadap profitabilitas. Capital adequacy ratio, loan to deposit ratio terbukti berpengaruh tidak signifikan terhadap profitabilitas. Penelitian ini memberikan kontribusi tentang faktor-faktor yang mempengaruhi prifitabilitas pada industri perbanakan.

\section{Pendahuluan}

PerbankanIndonesiadalammenjalankan fungsinya berasaskan prinsip kehati-hatian. Fungsi utama perbankan Indonesia adalah sebagai penghimpun dan penyalur dana masyarakat serta bertujuan untuk menunjang pelaksanaan pembangunan nasional dalam rangka meningkatkan pemerataan pembangunan 
dan hasil-hasilnya, pertumbuhan ekonomi dan stabilitas nasional, kearah peningkatan taraf hidup rakyat banyak. Agar bank-bank umum dapat menjalankan usahanya sesuai dengan tujuan pendiriannya, maka Bank Indonesia ditugaskan untuk membina dan mengawasi seluruh bank yang beroperasi di Indonesia, berdasarkan Undang-Undang No.10 tahun 1998 tentang perubahan Undang-Undang No.7 Tahun 1992 tentang Perbankan dan UndangUndang No.23 Tahun 1999 tentang Bank Indonesia. Salah satu tugas Bank Indonesia adalah membangun sistem perbankan yang sehat, dengan mewajibkan semua bank umum menyediakan laporan keuangan perbankan yang berkualitas dengan tingkat transparansi informasi yang memadai sebagai bagian penting dari good governance.

Salah satu langkah kongkrit yang ditempuh oleh Bank Indonesia adalah dengan membuat kebijakan yang mewajibkan bank untuk menyusun laporan keuangan secara transparan sesuai dengan standar-standar akuntansi yang berlaku, sehingga dapat berperan sebagai informasi yang bermanfaat yang dibutuhkan tidak hanya oleh pengelola bank itu sendiri, namun juga masyarakat dan stakeholder lainnya, terutama Bank Indonesia. Bagi Bank Indonesia sebagai pemegang kebijakan publik di bidang perbankan, laporan-laporan yang disampaikan oleh bank merupakan salah satu sumber informasi penting dalam melaksanakan fungsi pembinaan dan pengawasan bank. Untuk berjalannya fungsi tersebut, Bank Indonesia perlu memastikan bahwa informasi yang diterimanya berupa laporan keuangan yang telah diaudit adalah informasi yang handal, dapat dipahami, relevan dan tentu saja harus dapat diperbandingkan, sehingga penilaian atas kinerja keuangan bank dapat terlaksana dengan baik sesuai dengan ketentuan yang berlaku.

Tingkatkesehatan suatu bank merupakan kepentingan semua pihak terkait, baik pemilik, pengelola bank, masyarakat pengguna jasa bank dan Bank Indonesia selaku otoritas pengawasan bank. Pesatnya perkembangan yang terjadi di bidang perbankan berpengaruh pada meningkatnya kompleksitas usaha bank dan profil risiko yang dimiliki bank. Bagi Bank Indonesia, hasil analisis kinerja perbankan sangat diperlukan sebagai salah satu cara menilai keberhasilan bank dalam mengelolah dana-dana tersimpan di bank tersebut, dan alat ukur kinerja industri perbankan yang penting adalah Return on Assets. Selama enam tahun terakhir ini, sejak tahun 2007 sampai 2012, pertumbuhan Return on Asset relatif masih kecil, tidak sebanding dengan pertumbuhan Capital Adequacy Ratio, Loan to Deposit Ratio dan Net Interest Margin. Penurunan Operational Cost Ratio (rasio Biaya Operasional terhadap Pendapatan Operasional) dan Non Performing Loan tidak sebanding dengan kenaikan Return on Assets.

Return On Assets digunakan untuk menilai kinerja dan efektivitas dalam penggunaan aktiva perusahaan dalam menghasilkan laba. Return On Assets diperoleh berdasarkan perbandingan laba sebelum pajak dengan rata-rata total assets. Return On Assets merupakan kemampuan dari modal yang diinvestasikan ke dalam seluruh aktiva perusahaan untuk menghasilkan keuntungan. Semakin tinggi laba yang dihasilkan, maka semakin tinggi pula Return On Assets. Rasio ini penting bagi bank karena rasio ini menunjukkan tingkat efisiensi pengelolaan aktiva. Selain itu, Return On Assets juga digunakan perusahaan perbankan untuk mengukur efektivitas perusahaan di dalam menghasilkan keuntungan dengan memanfaatkan aktiva yang dimilikinya. Return On Assets merupakan rasio antara laba bersih sebelum pajak terhadap total aktiva bank (Selamet Riyadi, 2004, 137). Semakin besar ROA menunjukkan kinerja keuangan semakin baik, karena tingkat kembalian (return) semakin besar (Husnan, 1998). Tingkat profitabilitas merupakan indikator yang paling tepat untuk mengukur kinerja bank. Ukuran profitabilitas yang digunakan pada industri perbankan adalah Return On Assets (Sofyan, 2003, 194).

Menurut Surat Edaran BI No. 3/30/ DPNP tanggal 14 Desember 2001, rasio Return On Asset dapat diukur dengan perbandingan antara laba sebelum pajak terhadap total 
aset. Semakin besar Return On Asset akan menunjukkan kinerja keuangan yang semakin baik, karena tingkat kembalian (return) semakin besar. Return On Asset Jika pihak bank dapat menjaga kinerjanya dengan baik, terutama tingkat profitabilitas yang tinggi serta dapat memenuhi ketentuan prudential banking dengan baik, maka kemungkinan nilai saham dari bank yang bersangkutan di pasar sekunder dan jumlah dana dari pihak ketiga yang berhasil dikumpulkan akan ikut naik. Kenaikan tersebut merupakan salah satu indikator naiknya kepercayaan masyarakat kepada bank yang bersangkutan.

Tingkat kepercayaan masyarakat adalah fundamental bagi tumbuh atau hancurnya perbankan. Kinerja keuangan bank dapat dinilai dari rasio keuangan bank, seperti rasio Capital Adequacy Ratio, Loan to Deposit Ratio, Non Performing Loan, Posisi Devisa Netto, Net Interest Margin, Operational Costratio(BOPO). Menurut Peraturan Bank Indonesia No.6/10/ $\mathrm{PBI} / 2004$ tentang sistem penilaian tingkat kesehatan bank umum, dijelaskan bahwa untuk menilai kinerja keuangan perbankan digunakan lima aspek penilaian yaitu CAMEL, terdiri atas Capital, Asset, Management, Earning, dan Liquidity. Aspek capital (permodalan) meliputi Capital Adequacy Ratio, aspek assets (kualitas aktiva produktif) meliputi Non Performing Loan, aspek earning (rentabilitas) meliputi Net Interest Margin dan Operational Cost Ratio dan aspek liquidity meliputi Loan to Deposit Ratio dan Reserve Requirement Ratio (Giro Wajib Minimum). Empat dari lima aspek tersebut dinilai dengan menggunakan rasio keuangan, yaitu capital, assets, earning, dan liquidity Kinerja merupakan hal penting yang harus dicapai oleh setiap perusahaan perbankan dimanapun, karena kinerja merupakan cerminan dari kemampuan perusahaan perbankan dalam mengelola dan mengalokasikan sumber dayanya. Menurut Pandia (2012:71), Return on Asset merupakan indikator kemampuan perbankan untuk memperoleh laba atas sejumlah aset yang dimiliki oleh bank. Return on Asset ini akan menunjukkan tingkat efisiensi pengelolaan aset yang dilakukan oleh bank, sehingga berdampak pada kinerja keuangan bank. Sementara menurut Manurung dan Rahardja (2008:209-210), menyatakan ada dua aspek penting yang perlu diperhatikan dalam menganalisis kinerja keuangan perbankan, yaitu profitabilitas dan likuiditas. Menurutnya ukuran profitabilitas yang umum digunakan adalah Return on Asset, Return on Equity dan Net Interest Margin. Dikatakannya, indikator yang paling tepat untuk mengukur kinerja bank adalah Return on Assets, khususnya untuk sektor industri perbankan. Sedangkan Return on Equity biasanya digunakan untuk sektor industri lainnya, di luar perbankan. Return on Asset memfokuskan kemampuan perusahaan untuk memperoleh earning dalam operasi perusahaan, sedangkan Return on Equity hanya mengukur return yang diperoleh dari investasi pemilik perusahaan dalam bisnis tersebut, sehingga dalam penelitian ini Return on Assets digunakan sebagai ukuran kinerja perbankan.

Adapun alasan Return on Assets dipilih sebagai ukuran kinerja, dikarenakan return on Assets digunakan untuk mengukur efektivitas perusahaan perbankan di dalam menghasilkan keuntungan dengan memanfaatkan aktiva yang dimilikinya. Return on Asset merupakan rasio antara laba sebelum pajak terhadap total asset. Semakin besar return on asset menunjukkan kinerja keuangan yang semakin baik, karena return semakin besar. Apabila return on asset meningkat, berarti profitabilitas perusahaan perbankan meningkat, sehingga dampak akhirnya adalah peningkatan profitabilitas yang dinikmati oleh pemegang saham (Husnan, 2004)

Berdasarkan latar belakang tersebut, maka yang menjadi rumusan masalah dalam penelitian ini adalah :

1. Seberapa besar pengaruh Capital Adequacy Ratio, Loan to Deposit Ratio, Non Performing Loan, Operational Cost Ratio, dan Net Interest Margin secara simultan terhadap Return on Assets pada perusahaan perbankan yang terdagtar di Bursa Efek Indonesia periode 2007-2012? 
2. Seberapa besar pengaruh Capital Adequacy Ratio, Loan to Deposit Ratio, Non Performing Loan, Operational Cost Ratio, dan Net Interest Margin secara parsial terhadap Return on Assets pada perusahaan perbankan pada perusahaan perbankan yang terdagtar di Bursa Efek Indonesia periode 2007-2012?

\section{Telaah Teori dan Pengembangan Hipotesis}

\subsection{Pengertian Bank}

Pengertian bank menurut UndangUndang Republik Indonesia No. 7 Tahun 1992 tentang Perbankan, yang telah diubah dengan Undang-Undang No 10 Tahun 1998, Bank adalah badan usaha yang menghimpun dana dari masyarakat dalam bentuk simpanan dan menyalurkannya kepada masyarakat dalam bentuk kredit dan / atau bentuk-bentuk lainnya dalam rangka meningkatkan taraf hidup rakyat banyak. Selanjutnya menurut Hasibuan (2009:2), bank umum merupakan lembaga keuangan, pencipta uang, pengumpul dana dan penyalur kredit, pelaksana lalu lintas pembayaran, stabilisator moneter, serta dinamisator pertumbuhan perekonomian.

\subsection{Penilaian Tingkat Kesehatan Bank}

Dalam Surat Edaran Bank Indonesia No. 6/23/DPNP, dijelaskan bahwa Bank Indonesia memberikan penilaian atas tingkat kesehatan bank ke dalam 4 (empat) kategori, yaitu 1). predikat "Sehat", 2). predikat "Cukup Sehat", 3). predikat "Kurang Sehat" dan 4). predikat "Tidak Sehat". Untuk predikat Tingkat Kesehatan "Sehat" dipersamakan dengan Peringkat Komposit 1 (PK-1) atau Peringkat Komposit 2 (PK-2). Selanjutnya, untuk predikat Tingkat Kesehatan "Cukup Sehat" dipersamakan dengan Peringkat Komposit 3 (PK-3). Sedangkan, untuk predikat Tingkat Kesehatan "Kurang Sehat" dipersamakan dengan Peringkat Komposit 4 (PK-4). Terakhir, untuk predikat Tingkat Kesehatan "Tidak Sehat" dipersamakan dengan Peringkat Komposit 5
(PK-5).

\subsection{Laporan Keuangan}

Menurut Baridwan (2004:17), Laporan keuangan merupakan ringkasan dari suatu proses pencatatan, merupakan suatu ringkasan dari transaksi-transaksi keuangan yang terjadi selama tahun buku yang bersangkutan. Munawir (2007:2), Laporan keuangan adalah hasil dari proses akuntansi yang dapat digunakan sebagai alat untuk berkomunikasi antara data keuangan atau aktivitas suatu perusahaan dengan pihakpihak yang berkepentingan dengan data atau efektivitas perusahaan tersebut."

\subsection{Return on Assets}

Dalam penelitian ini Return on Asset dipilih sebagai indikator pengukur kinerja keuangan perbankan, karena Return on Asset digunakan untuk mengukur efektivitas perusahaan di dalam menghasilkan keuntungan dengan memanfaatkan aktiva yang dimilikinya. Semakin besar Return on Asset menunjukkan kinerja keuangan perusahaan semakin baik, karena tingkat kembalian (return) semakin besar. Apabila Return on Asset meningkat, berarti profitabilitas perusahaan meningkat, sehingga dampak akhirnya adalah peningkatan profitabilitas yang dinikmati oleh pemegang saham (Suad Husnan, 1998).

Menurut Timothy (1995: 14), dalam Manurung \& Rahardja (2004: 153), Return On Assets merupakan hasil perkalian (sinergi) antara tingkat profitabilitas bank (profit margin) dengan efisiensi penggunaan aktiva (assets utilization). Bila Return On Assets meningkat berarti tingkat profitabilitas dan atau efisiensi penggunaan meningkat. Sedangkan tingkat profitabilitas dapat dievaluasi dengan menggunakan indikator margin keuntungan (profit margin) dengan membagi laba bersih sebelum pajak dengan pendapatan total. Profit Margin yang makin besar menunjukkan pertumbuhan laba bersih sebelum pajak lebih tinggi dibanding pendapatan total. Dapat disimpulkan bahwa laba bersih sebelum pajak akan makin besar bila 
selisih positif antara total pendapatan dikurangi total biaya semakin besar. Untuk memperbesar selisih tersebut, maka perlu perbaikan di sisi biaya dan pendapatan. Di sisi pendapatan misalnya, bank umum harus meningkatkan jumlah dan kualitas aktiva produktif. Sementara di sisi biaya, penghematan tanpa menurunkan kualitas pelayanan mutlak dilakukan. Karena biaya total terdiri atas biaya bunga dan non bunga, maka efisiensi penggunaan dana dan penggunaan faktor produksi non dana, terutama tenaga kerja sangat dibutuhkan. Adapun ukuran tingkat penggunaan aktiva (assets utilization) adalah rasio antara total pendapatan dengan total aktiva. Tingkat penggunaan aktiva yang semakin baik disebabkan pertumbuhan pendapatan yang lebih tinggi dari pertumbuhan aktiva. Karena itu pendapatan bunga dan non bunga harus ditingkatkan dengan cara memperbanyak dan meningkatkan kualitas aktiva produktif, serta meningkatkan kuantitas dan kualitas produk jasa-jasa perbankan.
Menurut Riahi-Belkaoui (1998), Return on Assets digunakan untuk mengukur kinerja keuangan perusahaan-perusahaan multinasional khususnya jika dilihat dari sudut pandang profitabilitas dan kesempatan investasi. Sedangkan menurut Adeyemi-Belo (2000), Return on Asset digunakan untuk mengetahui hubungan antara organisasi dankinerjakeuangan bank-bank retail, sehingga strategi organisasi dalam menghadapi persaingan yang semakin ketat dapat diformulasikan. Di Indonesia, Bank Indonesia menetapkan angka Return On Assets $\geq 2 \%$ agar sebuah bank umum dapat dikatakan dalam kondisi sehat. Berdasarkan Surat Edaran Bank Indonesia No.6/73/INTERN DPNP tertanggal 24 Desember 2004, Return on Assets diformulasikan sebagai berikut :

Return on Asset $=\underline{\text { Laba bersih sebelum pajak }}$ Total Assets

\subsection{Penelitian Terdahulu}

Tabel 1.

Ringkasan Penelitian Terdahulu

\begin{tabular}{|c|c|c|c|}
\hline No. & Peneliti & Judul & Hasil Penelitian \\
\hline 1. & $\begin{array}{l}\text { Tri Widyastuti \& Yuna } \\
\text { Rizky Octaviani (2009) }\end{array}$ & $\begin{array}{l}\text { Pengaruh CAR, NIM dan LDR } \\
\text { terhadap ROA, Perusahaan } \\
\text { Perbankan yang Terdaftar di BEI } \\
\text { selama tahun 2004-2008 }\end{array}$ & $\begin{array}{l}\text { NIM dan CAR memiliki pengaruh } \\
\text { positif dan signifikan terhadap } \\
\text { ROA. Sedangkan LDR memiliki } \\
\text { pengaruh negatif dan signifikan } \\
\text { terhadap ROA. Pengaruh ketiga } \\
\text { variabel independen terhadap ROA } \\
\text { sebesar } 66,7 \% \text {. }\end{array}$ \\
\hline 2. & Kunto Wibisono (2011) & $\begin{array}{l}\text { Pengaruh CAR, NIM, LDR } \\
\text { dan NPL terhadap ROA pada } \\
\text { bank Umum Swasta Nasional } \\
\text { Indonesia }\end{array}$ & $\begin{array}{l}\text { NPL dan LDR tidak berpengaruh } \\
\text { signifikan dan negatif terhadap } \\
\text { ROA. Sedangkan CAR dan NIM } \\
\text { berpengaruh signifikan dan positif } \\
\text { terhadap ROA. Prediksi kapabilitas } \\
\text { dari keempat variabel di atas } \\
\text { terhadap ROA sebesar } 47 \% \text {. }\end{array}$ \\
\hline 3. & $\begin{array}{l}\text { Laila Suci Amalia dan A. } \\
\text { Mulyo Hariyanto (2010) }\end{array}$ & $\begin{array}{l}\text { Pengaruh CAR, NPL, NIM, } \\
\text { BOPO dan PPAP terhadap Kinerja } \\
\text { Rentabilitas bank, Studi Kasus } \\
\text { pada Bank Devisa dan Bank Non } \\
\text { Devisa tahun 2004-2008 }\end{array}$ & $\begin{array}{l}\text { CAR dan NPL berpengaruh } \\
\text { signifikan dan positif terhadap } \\
\text { ROA. Sedangkan BOPO memiliki } \\
\text { pengaruh signifikan dan negatif } \\
\text { terhadap ROA. Selanjutnya PPAP } \\
\text { dan LDR tidak memiliki pengaruh } \\
\text { signifikan dan negatif terhadap } \\
\text { ROA. NIM mempunyai pengaruh } \\
\text { signifikan terhadap ROA }\end{array}$ \\
\hline
\end{tabular}




\subsection{Kerangka Pemikiran}

Gambar 1.

Kerangka Pemikiran

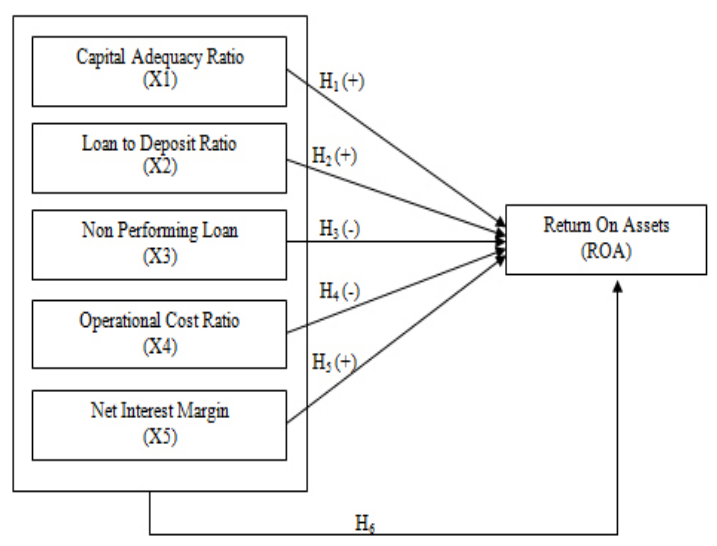

Perumusan Hipotesis :

H1: Capital Adequacy Ratio berpengaruh positif signifikan terhadap Return on Assets

H2: Loan to Deposit Ratio berpengaruh positif signifikan terhadap Return on Assets

H3: Non Performing Loan berpengaruh negatif signifikan terhadap Return on Assets

H4: Operational Cost Ratio berpengaruh negatif signifikan terhadap Return on Assets.

H5: Net Interest Margin berpengaruh positif signifikan terhadap Return on Assets

H6: Capital Adequacy Ratio, Loan to Deposit Ratio, Loan to Deposit Ratio, Non Performing Loan, Operational Cost ratio dan Net Interest Margin secara simultan berpengaruh secara signifikan terhadap Return on Assets perusahaan perbankan.

\section{Metode Penelitian}

Populasi yang digunakan dalam penelitian ini adalah seluruh perusahaan perbankan yang tercatat di Bursa Efek Indonesia (BEI) di tahun 2012 sebanyak 32 perusahaan. Teknik penentuan sampel dalam penelitian ini menggunakan purposive sampling, yaitu penentuan sample dengan berdasarkan pada kriteria-kriteria tertentu. Data yang dikumpulkan dalam penelitian ini adalah data sekunder sehingga metode pengumpulan data menggunakan cara non participant observation, yaitu peneliti tidak terlibat langsung dengan aktivitas yang sedang diamati, melainkan hanya sebagai pengamat independen. Metode analisis yang digunakan untuk menguji hipotesis adalah multivariate analysis, yaitu analisis yang dilakukan untuk menganalisa hubungan lebih dari dua variabel. Sedangkan model yang digunakan untuk penelitian ini adalah persamaan regresi linear berganda. Adapun persamaan regresi tersebut dapat dituliskan sebagai berikut :

$\mathrm{Y}=\alpha+\beta 1 \mathrm{CAR}+\beta 2 \mathrm{LDR}+\beta 3 \mathrm{NPL}+\beta 4$ $\mathrm{BOPO}+\beta 5 \mathrm{NIM}+€$

Untuk menjawab permasalahan yang akan dibahas, semua data yang telah dikumpulkan selanjutnya dianalisis dengan menggunakan uji statistik deskriptik, uji asumsi klasik, uji hipotesis (uji t statitik dan uji $\mathrm{F}$ statistik), uji model regresi berganda, dan uji koefisien determinasi.

\section{Hasil Penelitian dan Pembahasan}

Dengan melihat tabel sebelumnya, dapat disusun persamaan regresi linear berganda sebagai berikut:

$\mathrm{ROA}=7,018+0,008$ CAR $-0,004$ LDR $0,079 \mathrm{NPL}-0,076 \mathrm{BOPO}+0,273 \mathrm{NIM}$

Penjelasan persamaan tersebut sebagai berikut:

a. Konstanta sebesar 7,018; artinya jika CAR, LDR, NPL, BOPO dan NIM nilainya 0 , maka ROA nilainya sebesar 7,018.

b. Koefisien regresi variabel CAR sebesar 0.008; artinya jika CAR mengalami kenaikan 100\%, maka ROAakan mengalami kenaikan sebesar $0.8 \%$.

c. Koefisien regresi variabel LDR sebesar $-0.004 \%$; artinya jika LDR mengalami kenaikan 100\%, maka ROAakan mengalami penurunan sebesar $0.4 \%$.

d. Koefisien regresi variabel NPL sebesar $-0.079 \%$; artinya jika NPL mengalami kenaikan 100\%, maka ROAakan mengalami penurunan sebesar 7,9\%.

e. Koefisien regresi variabel BOPO sebesar $-0.076 \%$; artinya jika BOPO mengalami kenaikan 100\%, maka ROAakan mengalami penurunan sebesar 7,6\%.

f. Koefisien regresi variabel NIM sebesar 
$0.273 \%$; artinya jika NIM mengalami kenaikan 100\%, maka ROAakan mengalami kenaikan sebesar $27,3 \%$.

Berdasarkan hasil Uji F Statistik yang dilakukan di atas, dapat disimpulkan bahwa semua variabel independen (Capital Adequacy Ratio, Loan to Deposit Ratio, Non Performing Loan, Operational Cost Ratio (BOPO) dan Net Interest Margin) terbukti secara bersamasama (simultan) berpengaruh secara signifikan terhadap variabel dependen Return on Asset.

Selain itu nilai signifikansi dari Fhitung sebesar 0,00 dan ini jauh lebih kecil dari 0,05 atau $5 \%$, maka pemilihan model regresi dari variabel independen Capital Adequacy Ratio, Loan to Deposit Ratio, Non Performing Loan, Operational Cost Ratio (BOPO) dan Net Interest Margin yang digunakan untuk memprediksi Return on Asset secara bersamasama berpengaruh signifikan. Untuk pengujian uji t dapat disimpulkan sebagai berikut :

1. Variabel Capital Adequacy Ratio tidak terbukti berpengaruh signifikan positif terhadap variabel Return on Asset. Hal ini terlihat dari nilai signifikansi sebesar 0.419 , lebih besar dari 0,05, dan begitu pula dengan nilai t hitung lebih kecil dari nilai t tabel, nilai thitung 0,810 , sedangkan nilai $\mathrm{t}$ tabel 1.976. Dengan demikian hipotesis pertama yang menyatakan bahwa Capital Adequacy Ratio memiliki pengaruh signifikan positif terhadap Return on Asset ditolak.

2. Variabel Loan to Deposit Ratio tidak terbukti berpengaruh signifikan positif terhadap variabel Return on Asset. Hal ini terlihat dari nilai signifikansi sebesar 0.089 , lebih besar dari 0,05 , dan begitu pula dengan nilai t hitung lebih kecil dari nilai $\mathrm{t}$ tabel, nilai t hitung $-1,714$, sedangkan nilai $t$ tabel 1.976. Dengan demikian hipotesis kedua yang menyatakan bahwa Loan to Deposit Ratio memiliki pengaruh signifikan positif terhadap Return on Asset ditolak.

3. Variabel Non Performing Loan terbukti berpengaruh negatif secara signifikan terhadap variabel Return on Asset. Hal ini terlihat dari nilai signifikansi sebesar 0.000 , lebih besar dari 0,05 , dan begitu pula dengan nilai t hitung lebih besar dari nilai $\mathrm{t}$ tabel, yaitu nilai t hitung sebesar -3,769, sedangkan nilai $\mathrm{t}$ tabel 1.976. Dengan demikian hipotesis ketiga yang menyatakan bahwa Non Performing Loan memiliki pengaruh signifikan negatif terhadap diterima.

4. Variabel Operational Cost Ratio (BOPO) terbuktiberpengaruh negatif secara signifikan terhadap variabel Return on Asset. Hal ini terlihat dari nilai signifikansi sebesar 0.000 , lebih besar dari 0,05 , dan begitu pula dengan nilai thitung lebih besar dari nilai $t$ tabel, yaitu nilai thitung sebesar $-24,470$, sedangkan nilai $\mathrm{t}$ tabel 1.976 . Dengan demikian hipotesis keempat yang menyatakan bahwa Operational Cost Ratio (BOPO) memiliki pengaruh signifikan negatif terhadap diterima.

5. Variabel Net Interest Margin terbukti berpengaruh positif secara signifikan terhadap variabel Return on Asset. Hal ini terlihat dari nilai signifikansi sebesar 0.000 , lebih besar dari 0,05 , dan begitu pula dengan nilai t hitung lebih besar dari nilai t tabel, yaitu nilai t hitung sebesar 12,990, sedangkan nilai $\mathrm{t}$ tabel 1.976 . Dengan demikian hipotesis kelima yang menyatakan bahwa Net Interest Margin memiliki pengaruh signifikan positif terhadap Return on Assets bisa diterima.

Pengujian hipotesis penelitian dengan Uji-t terangkum dalam table berikut:

Tabel. 2

Hasil Pengujian Hipotesis

\begin{tabular}{crc}
\hline \multirow{2}{*}{ Variabel } & \multicolumn{2}{c}{ Hasil Uji } \\
& t-hitung & Sig \\
\hline (Constant) & 20.958 & .000 \\
CAR & .810 & .419 \\
LDR & -1.714 & .089 \\
NPL & -3.769 & .000 \\
BOPO & -24.470 & .000 \\
NIM & 12.990 & .000 \\
\hline
\end{tabular}


Dalam hipotesis pertama disebutkan bahwa Capital Adequacy Ratio berpengaruh positif secara signifikan terhadap Return on Asset. Berdasarkan hasil uji t yang dilakukan, diperoleh nilai signifikansi sebesar 0.419 , sedangkan koefisien regresi sebesar 0,008\%. Hal ini menunjukkan bahwa Capital Adequacy Ratio tidak berpengaruh signifikan terhadap Return on Asset, karena nilai signifikansinya lebih besar dari 0,05 yaitu sebesar 0,419 . Untuk koefisien regresi sebesar $0,008 \%$ berarti setiap kenaikan Capital Adequacy Ratio sebesar 100\% akan meningkatkan Return on Asset sebesar $0,8 \%$. Dengan demikian hipotesis pertama yang menyatakan bahwa Capital Adequacy Ratio memiliki pengaruh signifikan positif terhadap Return on Asset ditolak. Hal ini berarti kemampuan permodalan bank dalam menjaga kemungkinan timbulnya risiko kerugian kegiatan usahanya tidak berpengaruh terhadap tingkat pendapatan atau earning yang dihasilkan oleh bank tersebut, sehingga tidak mempengaruhi kinerja keuangan bank tersebut.

Hasil penelitian ini sesuai dengan hasil penelitian terdahulu dari Pramudya Harimurti dan Muniya Alteza (2011), menemukan bahwa Capital Adequacy Ratio tidak berpengaruh terhadap Return on Assets. Sejalan pula dengan teori yang dikemukan oleh oleh Mandala Manurung dan Prathama Rahardja (2008:211), yang menyatakan bahwa aspek permodalan merupakan elemen yang sangat penting dalam dunia perbankan, karena tingkat kesehatan sebuah bank umum dapat diukur dari ketaatan memenuhi ketentuan permodalan. Semakin tinggi Capital Adequacy Ratio suatu bank, mencerminkan tingkat likuiditas bank tersebut akan semakin tinggi, tetapi bukan sebagai penentu naiknya tingkat profitabilitas suatu bank. Dapat juga dikatakan bahwa semakin tinggi nilai Capital Adequacy Ratio semakin tinggi pula tingkat likuiditas bank tersebut, dan potensi untuk meningkatkan pendapatan atau keuntungan semakin tinggi pula, tetapi tidak secara otomatis semakin tinggi pula profit-nya melainkan ada faktor variabel lain yang ikut menentukan besarnya tongkat keuntungan yang diperoleh bank tersebut. Nilai rata-rata (mean) dari Capital Adequacy Ratio selama periode penelitian sebesar 10,8906\%, dan dalam penilaian Bank Indonesia masuk peringkat (rating) 1, yaitu sangat baik, melampui ketentuan yang dipersyaratkan.

Dalam hipotesis kedua disebutkan bahwa Loan to Deposit Ratio berpengaruh positif secara signifikan terhadap Return on Asset. Berdasarkan hasil uji t yang dilakukan, diperoleh nilai signifikansi sebesar 0,089, sedangkan koefisien regresi sebesar $-0,004 \%$. Hasil ini menunjukkan bahwa Loan to Deposit Ratio tidak memiliki pengaruh signifikan terhadap Return on Asset, karena nilai signifikansinya masih di atas 0,05 yaitu sebesar 0,089 . Untuk koefisien regresi sebesar $-0,004$ berarti setiap penambahan Loan to Deposit Ratio sebesar 100\% akan menurunkan Return on Asset sebesar 0,4\%. Dengan demikian hipotesis kedua yang menyatakan bahwa Loan to Deposit Ratio memiliki pengaruh yang positif terhadap Return on Asset ditolak.

Hasil temuan ini mendukung hasil penelitian terdahulu yang dilakukan oleh Laila Suci Amalia dan A. Mulyo Hariyanto (2010) dan Kunto Wibisono (2011). Hasil dari kedua penelitian tersebutjuga menyatakan bahwa Loan to Deposit Ratio tidak mempunyai pengaruh dan negatif terhadap Return on Asset. Hal ini berarti kemampuan bank dalam menyalurkan kredit dari pihak ketiga kepada pihak kreditur tidak berpengaruh terhadap tingkat pendapatan atau laba bank tersebut. Jika presentase penyaluran kredit terhadap dana pihak ketiga berada antara $85 \%$ sampai $110 \%$, maka bank tersebut dapat dikatakan mempunyai tingkat likuiditas yang baik, sehingga dapat dipastikan kinerja keuangan bank tersebut juga baik. Nilai rata-rata (mean) dari Loan to Deposit Ratio selama periode penelitian sebesar $78,1260 \%$, dan dalam penilaian Bank Indonesia masuk peringkat (rating) dua, yaitu dalam kategori cukup baik. Hal ini juga menunjukkan bahwa tingkat likuiditas suatu bank tidak mempunyai pengaruh yang cukup signifikan terhadap besar kecilnya perolehan laba bank. Jika bank 
dalam menyalurkan kredit dari dana pihak ketiganya tinggi, maka dapat dikatakan tingkat likuiditasnya juga tinggi karena dana pihak ketiga dapat dimaksimalkan penggunaannya dalam bentuk kredit. Dengan tingginya penyaluran kredit, maka pendapatan bunga kredit juga akan meningkat, yang berdampak pada tingginya perolehan laba bank. Dilihat dari sisi manajemen bank, Loan to Deposit Ratio merupakan faktor yang cukup penting dalam menjalankan kegiatan usahanya, dan merupakan keharusan bagi bank untuk selalu menjaga rasio Loan to Deposit Ratio pada tingkat yang aman, sesuai dengan yang ditetapkan Bank Indonesia, yaitu 85\%-110\% (Mandala Manurung: 2008212). Dengan optimalnya Loan to Deposit Ratio dalam kegiatan usahanya, diharapkan bank akan mendapatkan keuntungan. Semakin likuid suatu bank, dapat dipastikan kelangsungan hidup bank tersebut akan berlangsung lama, dan kinerja keuangan yang dicapai perusahaan perbankan dapat terus meningkat.

Dalam hipotesis ketiga disebutkan bahwa Non Performing Loan berpengaruh negatif secara signifikan terhadap Return on Asset. Berdasarkan hasil uji t yang dilakukan, diperoleh nilai signifikansi sebesar 0.000 , dan nilai koefisien regresi sebesar $-0,079 \%$. Hasil ini menunjukkan bahwa Non Performing Loan berpengaruh secara signifikan dan negatif terhadap Return on Asset, karena nilai signifikansinya lebih kecil dari 0,05 , yaitu 0.000, maka dalam hal ini Non Performing Loan berpengaruh signifikan terhadap Return on Asset. Untuk koefisien regresi sebesar -0,079\% berarti setiap kenaikan Non Permorning Loan sebesar 100\% akan menurunkan Return on Asset sebesar 7,9\%. Dengan demikian hipotesa ketiga yang menyatakan bahwa Non Performing Loan berpengaruh negatif dan signifikan terhadap Return on Asset dapat diterima,

Hasil temuan ini sejalan dengan penelitian yang dilakukan oleh Pandu Mahardian (2008); Ahmad Buyung Nusantara (2009); dan Hardiyanti (2011), yang menyatakan bahwa Non Performing Loan berpengaruh signifikan dan negatif terhadap perubahan laba, dan tentunya mempengaruhi besar kecilnya nilai Return on Asset, karena laba merupakan komponen pembentuk Return on Asset. Hal ini berarti selama periode penelitian, fungsi intermediasi bank berjalan dengan semestinya dan semakin membaiknya perekonomian di sektor riil, sehingga berdampak pada turunnya rasio Non Performing Loan dan akan disertai dengan naiknya rasio Return on Asset. Secara umum, rata-rata Non Performing Loan bank-bank yang tercatat di Bursa Efek Indonesia masih berada dibawah 5\%, yaitu sebesar 2,3980\%. Menurut penilaian Bank Indonesia NPL dibawah 5\% masih dalam kategori "sehat", sehingga pengaruhnya terlihat dari pertumbuhan Return on Asset bank tersebut meningkat.

Dalam hipotesis keempat disebutkan bahwa Operational Cost Ratio (BOPO) berpengaruh negatif secara signifikan terhadap Return on Asset. Berdasarkan hasil ujin $\mathrm{t}$ yang dilakukan, diperoleh nilai signifikansi sebesar 0.000 , sedangkan koefisien regresi sebesar -0,076. Hasil ini menunjukkan bahwa Operational Cost Ratio (BOPO) memiliki pengaruh negatif signifikan terhadap Return on Asset, Karena nilai signifikansinya lebih kecil dari 0,05 yaitu sebesar 0,000. Untuk koefisien regresi sebesar $-0,076$ berarti setiap kenaikan Operational Cost Ratio (BOPO) sebesar 100\% akan menurunkan Return on Asset sebesar $7,6 \%$. Dengan demikian hipotesis keempat yang menyatakan bahwa efisiensi operasi memiliki pengaruh yang negatif terhadap Return on Asset diterima. Hasil temuan ini mendukung hasil penelitian terdahulu yang dilakukan oleh Kartika Wahyu Sukarno dan Muhamad Syaichu (2006); Pandu Mahardian (2008); Ahmad Buyung Nusantara (2009); Laila Suci Amalia dan A. Mulyo Hariyanto (2010); Aluisius Wishnu Nugroho (2011) dan Kunto Wibisono (2011). Pada penelitian yang mereka lakukan disimpulkan bahwa Operational Cost Ratio (BOPO) atau efisiensi operasi berpengaruh negatif dan signifikan terhadap Return on Asset. Hal ini berarti tingkat efisiensi bank dalam menjalankan operasinya, berpengaruh terhadap tingkat pendapatan atau earning yang dihasilkan 
oleh bank tersebut. Jika kegiatan operasional dilakukan dengan efisien, dalam hal ini nilai Operational Cost Ratio (BOPO) rendah, maka pendapatan yang dihasilkan bank tersebut akan naik. Untuk sebuah lembaga keuangan bank, penekakan terhadap efisiensi operasi merupakan faktor yang sangat penting bagi kelangsungan hidup bank tersebut dan efisiensi operasi sangat mempengaruhi besar kecilnya return yang diperoleh suatu bank. Semakin efisien kegiatan operasi yang dilakukan oleh suatu bank, maka laba yang diperoleh bank tersebut akan semakin besar. Nilai rata-rata (mean) dari Operational Cost Ratio (BOPO) selama periode penelitian sebesar 80,9928\%, dan dalam penilaian Bank Indonesia masuk kategori "baik", masih dibawah 90\%, meskipun Bank Indonesia menghimbau pihak manajemen bank agar menurunkan Operational Cost Ratio (BOPO) dibawah angka $80 \%$.

Dalam hipotesis kelima disebutkan bahwa Net Interest Margin berpengaruh positif secara signifikan terhadap Return on Asset. Berdasarkan hasil uji t yang dilakukan, diperoleh nilai signifikansi sebesar 0,000, sedangkan koefisien regresi sebesar 0,273 . Hasil ini menunjukkan bahwa Net Interest Margin memiliki pengaruh positif signifikan terhadap Return on Asset, karena nilai signifikansinya lebih kecil dari 0,05 yaitu sebesar 0,000. Untuk koefisien regresi sebesar 0,273 berarti setiap kenaikan Net Interest Margin sebesar 100\% akan meningkatkan Return on Asset sebesar 27,3\%. Dengan demikian hipotesis kelima yang menyatakan bahwa Net Interest Margin memiliki pengaruh yang positif terhadap Return on Asset diterima. Hasil temuan ini mendukung hasil penelitian terdahulu yang dilakukan oleh Pandu Mahardian (2008); Tri Widyastuti dan Yuna Rizky Octaviani (2009); Laila Suci Amalia dan A. Mulyo Hariyanto (2010); dan Kunto Wibisono (2011), yang menyatakan bahwa Net Interest Margin mempunyai pengaruh positif dan signifikan terhadap Return on Asset. Hal ini berarti kemampuan manajemen bank dalam menghasilkan bunga bersih berpengaruh terhadap tingkat pendapatan bank akan total assetnya. Bunga bersih merupakan salah satu komponen pembentuk laba (pendapatan), karena laba merupakan komponen pembentuk Return on Asset, maka secara tidak langsung jika pendapatan bunga bersih meningkat maka laba yang dihasilkan bank juga akan meningkat, sehingga akan meningkatkan kinerja keuangan bank tersebut. Bagi pihak manajemen bank, rasio Net Interest Margin menunjukkan seberapa besar bunga bersih yang diperoleh bank, sebagai penyalur dana kepada pihak yang membutuhkan. Karena kegiatan usaha pokoknya tersebut, maka rasio Net Interest Margin merupakan faktor yang penting bagi kelangsungan hidup bank tersebut, dan pihak manajemen bank harus selalu berupaya agar rasio Net Interest Margin berada pada posisi yang cukup tinggi, sehingga laba yang diperoleh akan tetap tinggi. Dengan tingginya laba yang diperoleh, maka kinerja keuangan tersebut akan meningkat pula. Nilai rata-rata (mean) dari Net Interest Margin selama periode penelitian sebesar 4,8594\%, dan dalam penilaian Bank Indonesia masuk peringkat (rating) satu, artinya margin bunga sangat tinggi

Dalam hipotesis keenam disebutkan bahwa Capital Adequacy Ratio, Loan to Deposit Ratio, Non Performing Loan, Operational Cost Ratio (BOPO) dan Net Interest Margin secara simultan berpengaruh signifikan terhadap Return on Asset. Berdasarkan hasil uji F yang dilakukan, dapat disimpulkan bahwa hipotesis keenam yang menyatakan semua variabel independen (Capital Adequacy Ratio, Loan to Deposit Ratio, Non Performing Loan, Operational Cost Ratio (BOPO) dan Net Interest Margin) secara bersama-sama berpengaruh secara signifikan terhadap variabel dependen Return on Asset diterima. Bisa diartikan bahwa Capital Adequacy Ratio, Loan to Deposit Ratio, Non Performing Loan, Operational Cost Ratio (BOPO) dan Net Interest Margin secara simultan berpengaruh signifikan terhadap Return on Asset. Hal ini dapat dibuktikan dari nilai $F$ hitung sebesar 243,578 dengan nilai signifikansi 0,00 . Karena nilai signifikansi jauh lebih kecil dari 0,05 atau 5\%, maka model regresi 
dapat digunakan untuk memprediksi Return on Asset dan variabel-variabel independen seperti Capital Adequacy Ratio, Loan to Deposit Ratio, Non Performing Loan, Operational Cost Ratio (BOPO) dan Net Interest Margin secara bersama-sama berpengaruh terhadap Return on Asset Hasil temuan ini mendukung hasil penelitian terdahulu yang dilakukan oleh Tri Widyastuti dan Yuna Rizky Octaviani (2009); dan Laila Suci Amalia dan A. Mulyo Hariyanto (2010).

\section{Simpulan, Keterbatasan dan Implikasi Hasil Penelitian}

Berdasarkan hasil analisis regresi berganda menunjukkan bahwa sebagian hipotesis diajukan diterima, dalam arti terdapat pengaruh yang signifikan antara variabel independen dan variabel dependen. Adapun hasil analisis adalah sebagai berikut :

1. Capital Adequacy Ratio secara parsial tidak memiliki pengaruh signifikan positif terhadap Return on Asset.

2. Loan to Deposit Ratio secara parsial tidak memiliki pengaruh signifikan terhadap Return on Assets.

3. Non Performing Loan, pada penelitian ini secara parsial memiliki pengaruh negatif yang signifikan terhadap Return on Asset.

4. Operational Cost Ratio (BOPO) secara parsial memiliki pengaruh negatif secara signifikan terhadap Return on Assets.

5. Net Interest Margin secara parsial memiliki pengaruh positif secara signifikan terhadap Return on Asset.

6. Secara simultan, kelima variabel independen, yaitu Capital Adequacy Ratio, Loan to Deposit Ratio, Non Performing Loan, Operational Cost Ratio dan Net Interest Margin berpengaruh signifikan terhadap Return on Asset.

Adapun keterbatasan yang terdapat dalam penelitian ini yaitu :

1. Sampel perusahaan yang digunakan pada penelitian ini relatif sedikit, hanya 26 bank. Hal ini karena sampel yang diambil hanya pada perusahaan perbankan yang tercatat di Bursa Efek Indonesia.

2. Periode pengamatan yang digunakan di dalam penelitian ini relatif singkat, yakni hanya 6 tahun, yaitu dari 2007 sampai 2012.

3. Hasil penelitian ini menunjukkan pula bahwa pengaruh variabel independen dalam mempengaruhi variabel dependen, yaitu sebesar $88,7 \%$ dan sisanya sebesar $11,3 \%$ dipengaruhi oleh faktor-faktor lain yang tidak dimasukkan dalam model regresi, seperti faktor ekonomi negara secara makro serta faktor kondisi politik negara.

Berdasarkan keterbatasan sebelumnya makan saran yang diberikan oleh penelitian ini adalah, pertama, manajemen bank perlu merumuskan strategi penyaluran kredit agar bisa dilaksanakan secara maksimal dengan memanfaatkan peluang yang ada dan mengacu pada ketentuan Bank Indonesia. Jika hal itu bisa dilakukan, maka potensi untuk meningkatkan laba menjadi lebih besar dan kinerja keuangan bank akan meningkat pula. Nilai Loan to Deposit Ratio yang rendah mencerminkan banyak dana belum termanfaatkan dengan baik (idle fund), tidak terserap pasar dan jika dibiarkan terus, akan mempengaruhi kinerja keuangan bank itu. Kedua, Manajemen bank harus selalu menjaga agar rasio Net Interest Margin berada pada posisi yang tinggi sehingga laba yang diperoleh juga akan tinggi. Dengan tingginya laba yang diperoleh maka kinerja keuangan bank tersebut akan meningkat pula. Namun demikian, manajemen bank perlu mewaspadai bahwa selisih bunga yang semakin besar, bisa menunjukkan bank tersebut tidak efisien. Kekurangefisienan tersebut bisa timbul dari internal bank, seperti biaya operasional yang tinggi, yang memaksa bank menaikkan tingkat bunga kredit. Ketiga, manajemen bank diharapkan agar selalu meningkatkan rasio kecukupan modalnya (Capital Adequacy Ratio). Dengan modal yang cukup, bank tersebut akan memiliki tingkat likuiditas yang tinggi, sehingga bank tersebut bisa dipercaya 
masyarakat. Masyarakat akan menempatkan dana investasinya di bank tersebut, kemudian bank akan menyalurkan dana tersebut ke masyarakat dalam bentuk kredit, dan bank akan memperoleh pendapatan dari bunga kredit. Dengan naiknya pendapatan, kinerja keuangan bank akan meningkat pula. Terakhir, manajemen bank diharapkan mampu menurunkan nilai Operational Cost Ratio (rasio BOPO), karena makin kecil nilai rasio BOPO akan semakin baik baik bank itu. Nilai rasio BOPO yang rendah mencerminkan manajemen bank mampu mengendalikan biaya operasionalnya terhadap pendapatan operasionalnya, sehingga bank tersebut menjadi lebih efisien dan tidak dalam kondisi bermasalah.

\section{Daftar Pustaka}

Amalia, Laila Suci, dan A. Mulyo Hariyanto, Pengaruh CAR, NPL, NIM, BOPO dan PPAP terhadap Kinerja Rentabilitas Bank, Studi Kasus pada Bank Devisa dan Bank Non Devisa tahun 2004 - 2008.

Baridwan, Zaki, Intermediate Accounting, BPFE Yogyakarta, Edisi Kedelapan, 2010.

Hardiyanti (2011), Pengaruh CAR, NPL dan LDR terhadap ROA Pada bank BUMN yang Go-Publik di Indonesia, Tahun 2006 2010, Makassar, Universitas Hasanuddin.

Harimurti, Pramudya \& Alteza, Muniya, Pengaruh CAR, NPL, BOPO, LDR, NIM terhadap Profitabilitas Bank (Studi Bank Umum Konvensional terdaftar di Bursa Efek Indonesia, 2008-2011), Jurnal Manajemen Bisnis Indonesia Vol.2 Edisi 1, Universitas Negeri Yogyakarta, 2012.

Mahardian, Pandu., Analisis Pengaruh Rasio CAR, BOPO, NPL, NIM dan LDR terhadap Kinerja Keuangan Perbankan, Studi Kasus Perusahaan Perbankan yang Tercatat di BEJ Periode Juni 2002 - Juni 2007 (tesis), Semarang, Universitas Diponegoro, 2008.

Manurung, Mandala dan Rahadja, Prathama. Uang, Perbankan dan Ekonomi Moneter (Kajian Kontekstual Indonesia), LPFEUI, Jakarta, 2004.
Munawir, S, Analisa Laporan Keuangan, Edisi Keempat, Penerbit Liberty, Yogyakarta, 2010.

Nugroho, Aluisius Wishnu (2011), Analisis Pengaruh FDR, NPF, BOPO, KAP dan PLO Terhadap Return on Assets, Studi Pada Bank Syariah di Indonesia Periode 20062010, Semarang: Universitas Diponegoro.

Nusantara, Ahmad Buyung, Analisis Pengaruh

NPL, CAR, LDR dan BOPO terhadap Profitabilitas Bank, Perbandingan Bank Umum Go Publik dan Bank Umum Non Go Publik Periode 2005- 2007 (tesis), Semarang: Universitas Diponegoro, 2009.

Pandia, Frianto., Manajemen Dana dan Kesehatan Bank, PT Rineka Cipta, Jakarta, 2012.

20 Januari 2005, tentang Penilaian Kualitas Aktiva Bank Umum.

Riyadi, Selamet, Banking Assets and Liability Management, Jakarta: Lembaga Penerbit FEUI, 2006.

Sofyan, Sofriza, 2003, "Pengaruh Struktur Pasar terhadap Kinerja Perbankan di Indonesia", Media Riset \& Manajemen, Vol.2, No.3, Desember, pp.194-219.

Sukarno, Kartika Wahyu \& Syaichu Muhamad, Analisis Faktor-Faktoryang Mempengaruhi Kinerja Bank Umumdi Indonesia, Jurnal Studi Manajemen dan Organisasi, Volume 3 No.2 Juli 2006, Undip, Semarang

Surat Edaran Bank Indonesia No.3/30 DPNP tanggal 14 Desember 2001, Perihal Pedoman Perhitungan Rasio Keuangan (Lampiran 14)

Surat Edaran Bank Indonesia No.6/23/DPNP tanggal 31 Mei 2004, perihal Sistem Penilaian Tingkat Kesehatan Bank Umum Surat Edaran Bank Indonesia No.6/73/ Intern DPNP tanggal 24 Desember 2004, Perihal Pedoman Sistem Penilaian Tingkat Kesehatan Bank Umum (CAMELS Rating).

Timothy, Koch W., Bank Management, The Dryden Press, 1995.

Undang-Undang RI, No. 7 Tahun 1992 tentang 


\section{Perbankan}

Undang-Undang RI, No. 10, Tahun 1998 tentang Perbankan

Wibisono, Kunto, Pengaruh CAR, NPL, NIM,

LDR terhadap ROA pada Bank Umum Swasta Nasional di Indonesia, periode 2006 $-2010$

Widyastuti, Tri, Mandagie, Yuana Rizky Octaviani, Pengaruh CAR, NIM dan LDR terhadap ROA pada PerusahaanPerbankan, Jurnal Akuntansi Keuangan, Akuntabilitas Vol. 10 No.1, FEUP, September 2010. 